\title{
CELEBRATING THE PAST: HORACE'S ODES AS AIDE MÉMOIRE
}

\author{
S Thom (Stellenbosch University)
}

\section{In Travels with Herodotus Ryszard Kapuscinski writes:}

Herodotus admits that he was obsessed with memory, fearful on its behalf. He felt that memory is something defective, fragile, impermanent - illusory, even. That whatever it contains, whatever it is storing, can evaporate, simply vanish without a trace. His whole generation, everyone living on earth at that time, was possessed by that same fear. Without memory one cannot live, for it is what elevates man above beasts, determines the contours of the human soul; and yet it is at the same time so unreliable, elusive, treacherous. It is precisely what makes man so unsure of himself ... In the world of Herodotus, the only real repository of memory is the individual (2008:75-76).

In this discussion of memory, Kapuscinski does not ask what memory is. He simply assumes a very basic definition namely that memory's primary function is to preserve what has gone before. ${ }^{1}$ However, Kapuscinki's reflection on why an "unsuccessful process" such as memory is so fundamental, is more interesting. Memory provides a starting point. One cannot step into the same river twice, but at least the river of memory is there. Without memory no progress of any kind would be possible. Memory establishes what the past contained so that the present can move forward. This is the very basis for all human development. The fact is, as individuals and collectively, we cannot and do not have to start over all the time. Because it already contains the past - even though a fragmented past - memory provides us with a springboard into the future.

Taking the importance of memory as a given, I would like to consider briefly why Horace would engage with and celebrate the past so consistently. Subsequently I would like to consider more carefully how this celebration of the past functions as an aide-mémoire for his audience.

One of the most pervasive of ancient topoi is the belief that immortality is dependent on memory, for if a person's deeds or works are not remembered such a person's existence is eventually wiped out as if it had never happened. Pindar's claim to fame is not only that he writes memorable poetry. ${ }^{2}$ His poetry, because it is memorable, will grant immortality to whatever object or person he chooses to mention "for great deeds of valour / remain in deep darkness when they lack hymns"

1 Kapuscinski goes on to point out that memory is seldom successful since it is in flux and continually transforms what it preserves. This is true on the individual level, where ordinary forgetfulness as well as ongoing attempts to make sense of the past has a powerful effect. Memory is equally unsuccessful on the collective level, since it preserves a collection of different individual and often disparate experiences to begin with.The ongoing oral transmission of a people's experience is a basic attempt to aid memory.

2 Pindar: Nemean 7.62-64: "I shall bring genuine fame with my praises to the man who is my friend, for that is the proper reward for good men." 
(Pindar Nemean 7.14). ${ }^{3}$ Catullus can threaten permanent damnation in his poetry, because just like the gods, his poetry remembers (di meminerunt, meminit Fides, 30.11). ${ }^{4}$ Augustus may list his achievements in the Res Gestae, but he needs a Virgil to remind the Roman people of their pre-history in poetry. Virgil's poetry - because it will be remembered - will also immortalise the new empire where Augustus Caesar, Divi genus is at its helm (Aeneid 6.792). ${ }^{5}$

As most ancients Horace sees being remembered as proof of immortality. He picks up on this essential aspect of poetry in much the same way as Pindar does. ${ }^{6}$ In Odes 4.9 Horace points out that:

many brave men lived before Agamemnon,

but they [are] all bogged-down in never-ending night, un-mourned, unheard of ...

because they had no special poet, no Homer, to immortalise and proclaim their deeds. ${ }^{7}$ Horace goes on to emphasize that there is no difference between a life of glory and one of insignificance when both are followed by an "unremembered" death

3 Cf. also other instances in Pindar such as Nemean 7.12-17: "If a man succeeds in an exploit, he casts a honey-minded / cause [theme for a song] into the Muses' streams, for great deeds of valor / remain in deep darkness when they lack hymns. We know of a mirror for noble deeds in only one way / if, by the grace of Mnemosyne with the shining crown, / one finds a recompense for his labours / in poetry's famous songs;" Nemean 7.20-22: “I believe that Odysseus' story / has become greater than his actual suffering / because of Homer's sweet verse, for upon his fictions and soaring craft / rests great majesty, and his skill / deceives with misleading tales" and Nemean 7.30-35: "But to all alike comes / the wave of Hades and it falls upon the obscure / and the famous; yet honor belongs to those whose fair story a god exalts after they die. As a helper, then, I have come to the great navel of the broad-bosomed earth." The Pindar translations are those of Race in the Loeb collection.

4 si tu oblitus es, at di meminerunt, meminit Fides, but - if you [Alfenus] have forgotten, the gods remember, Fate remembers, Catullus 30.11. (All translations from Latin are my own.) Pindar too asserts this perspective in his first Olympian (1.63-65): "But if any man hopes to hide any deed from a god, he is mistaken."

5 hic Caesar et omnis Iuli / progenies, magnum caeli ventura sub axem. / hic vir, hic est, tibi quem promitti saepius audis, / Augustus Caesar, Divi genus, aurea condet / saecula qui rursus Latio regnata per arva / Saturno quondam, super et Garamantas et Indos / proferet imperium (iacet extra sidera tellus, / extra anni solisque vias. Here is Caesar and the whole generation of Iulus, about to come in under the huge dome of the sky. He is the man, he it is whom more and more often you hear was promised to you - Augustus Caesar, descendant of a god, who will establish again the golden times in Latium on the fields once reigned by Saturn and who will enlarge his empire beyond the peoples of Garamant and India to a land that lies beyond the stars, beyond the pathways of the years and of the sun, Aen. 6.789-796. See also Horace Odes 1.12 where Augustus is indicated in terms of Republican exempla (Gowing 2005:20-21).

6 Pindar Olympian 10. 91-94: "so, when a man who has performed noble deeds, Hagesidamos, goes without song to Hades' dwelling, in vain has he striven and gained for his toil but brief delight;" Pythian 3.114-115: " excellence endures in glorious songs for a long time;" Nemean 4. 6-8: "For the word lives longer than deeds, which, with the Graces' blessing, the tongue draws from the depths of the mind" and finally Nemean 6.28-31: "because when men are dead and gone, songs and words preserve for them their noble deeds."

vixere fortes ante Agamemnona / multi: sed omnes inlacrimabiles / urgentur ignotique longa / nocte, carent quia vate sacro, Odes 4.9.24-28. 
- that is a death not remembered in literature. ${ }^{8}$ Memory then - or to be remembered is essential for immortality, and poetry in all its facets, is a fundamental aide for memory.

The first point Horace aims to establish in his Odes is the "unceasing memory" or the immortality of his work. He opens his book of Odes, his magnum opus, with a reminder to his audience that evergreen ivy - a symbol of immortality will link him as a poet to the immortals. He has no doubts about the quality of the work that will justify this immortality. He acknowledges that there is only one condition, namely that two of the daughters of Memory, the muses, Euterpe and Polyhymnia, should do their duty and guarantee "remembrance" of his work. The prerequisite for immortality then is ongoing or unceasing memory of his achievement.

Having opened his collection of odes with the theme of immortality, Horace returns to this theme at the end of Book 2 and again at the end of Book 3. Both books conclude with Horace stating with absolute certainty that he will not die, since his poetry that is, the physical reminder of his work, guarantees his immortality. In Odes 2.20.5-7 his transformation is already taking place. He is no longer earth-bound, but will soon transcend time and space as a creature of the air. ${ }^{9}$ Odes Book 3 concludes with yet another statement of absolute certainty: as long as his poetry is remembered, the most significant part of him - his work - will have escaped death. ${ }^{10}$ Of course Horace does not deny his physical death. He merely affirms the general belief that remembrance of his poetry grants him immortality.

It is clear that Horace uses the lyric tradition that preceded him as springboard for taking his own work into the future. Like any artist, he takes into account the efforts of those who went before him. By recalling the past so consistently Horace claims an established and recognisable context. Because of this context he can claim legitimacy for his own efforts in continuing a well-honed tradition. Furthermore there is a distinct advantage in suggesting that a new collection of poems continues a tradition of past achievements already recognised for their quality and durability. And if this is the case, reminding the audience repeatedly of the past which he claims to continue and surpass, makes further good sense.

There is a further reason why Horace celebrates the past so consistently. If, as Kapuscinski points out, the only real repository of memory is the individual, the burden of memory falls on the individual. If Horace takes up the burden of "lyric memory", he (through his work) becomes the repository for that memory. His audience may share this memory but they are not the final repository for memory. His work represents the means by which the transmission of that memory becomes possible - to the audience of the present as well as the future. His work therefore has to ensure the continuation or "immortality" of the memory of his lyric achievement.

\footnotetext{
8 paulum sepultae distat inertiae / celata virtus, hidden [unproclaimed] honour differs little from buried insignificance, Odes 4.9.29-30.

9 et album mutor in alitem, and I am changing into a white swan, Odes 2.20.10.

10 non omnis moriar multaque pars mei / vitabit Libitinam, I shall not die completely and a large part of me shall avoid death, Odes 3.30.6-7.
} 
But memory is not the only guarantee of or requirement for immortality. There is another prerequisite, namely quality. ${ }^{11}$ How Horace wrote is therefore of paramount importance because the quality of his work was the fundamental prerequisite for the survival of the work. In short immortality for Horace is not only dependant on the aid of Mnemosyne and the Muses but also on producing the kind of work that deserved to be remembered. Horace himself - with the aid of Mnemosyne and the Muses - grants immortality to his predecessors and his peers by quoting or reflecting them in work of outstanding quality. The quality of Horace's work serves as a direct reminder of his predecessors, since he has to match or surpass them to claim the poets' prize that would elevate him to his rightful place amongst the immortal gods (Odes 1.1.29-30). ${ }^{12}$ To achieve this objective - of granting as well earning immortality through his work - Horace has to keep reminding his audience of the benchmarks he aims to achieve or surpass.

The scholarship on Horace's use of these reminders to his audience is vast and seemingly unending. The fact that Horace reflected the work of individual early Greek lyric poets or of his more immediate precursors, the Alexandrians, is indicated as a matter of course in commentaries on Horace. ${ }^{13}$ Scholarship may further encompass the tracing of verbal echoes, contextual similarities, generic applications or enhancements, or engaging in general with the "intertextuality" presented in Horace's work. Together these reminders function as an aide-mémoire and contribute directly and in an on-going manner to his audience's remembrance of his predecessors.

One of the most direct ways of remembering something is to make a list. ${ }^{14}$ In claiming to implement the same tool as his Greek precursors, Horace unfortunately does not list the Greek lyric poets on whose individual metrical examples he based his own poetry. However, in his fourth book of Odes, ${ }^{15}$ Horace does list a number of poets by name. In Odes 4.9 he specifically mentions Pindar (4.9.6), ${ }^{16}$ Alcaeus (4.9.7),

11 Horace based his claim on immortality consistently on the quality of his work. It is important to remember that Horace's reminder to his audience of what went before consists of two aspects: that which needed to be remembered (the "who" or "what" Horace portrays in his poetry) as well as the "memorable action" proclaiming this incident - in this case how Horace constructed poetry that became an instrument of remembrance.

12 me doctarum hederae praemia frontium / dis miscent superis, ivy, prize of learned heads, puts me amongst the gods above, Odes 1.29-30.

13 Nisbet \& Rudd 2004:53-54, for instance, indicates that Odes 3.4 reflects Pindar Pythian 1 and suggests possible aims of the poet in making use of material from a number of other predecessors. The impact of such references too will be discussed. Such usage may refer as well as give raise to a number of scholarly articles where the suggested contribution of the original to the Horatian poem will be discussed at length.

14 In Epistles 1.19.21-25 and 32-33 Horace states that he was the first to portray Greek poetic forms in Latin. In this section he mentions Archilochus and Alcaeus specifically as never having been used in this way in Latin before. For a full discussion, see McNeill 2007:363.

15 Horace's fourth Book of Odes was an afterthought which he was loath to publish, as is clear from parce, precor, precor / ... desine dulcium / mater saeva Cupidum ... flectere mollibus / iam durum imperiis, Spare me, I beg, I beg ... O harsh mother of sweet Cupids, stop [trying to] turn back one already impervious to your gentle orders, Odes 4.2.4-7. 
Anacreon (4.9.9) and Stesichorus (a Sicilian Greek poet) (4.9.8). He refers to the Greek elegist Simonides (4.9.7) by referring to his place of origin, Ceos, implying that he is so well-known that mention of his birthplace is sufficient to recall the poet. The Greek epic poet Homer (4.9.6) is indicated as being in a class of his own. The Greek lyric poetess Sappho is not mentioned by name ${ }^{17}$, but she is portrayed by means of describing the effect of her poetry in great detail. ${ }^{18}$ Listing these poets then is the most direct and simple way to remind the audience of the early Greek lyric poets in whose footsteps Horace so clearly follows and whose tradition he continues so successfully. ${ }^{19}$

Horace himself claimed that he would be remembered for being the first to adapt a Greek tool (metre) for transmitting Latin thought, or as he puts it to fit Aeolian song to Latin verse. ${ }^{20}$ Just how difficult this must have been becomes clear when we look for instance at two other quintessentially Roman poets - one who preceded and one who followed Horace. The natural flow of Catullan hendecasyllables depends on a metre that seems ideally suited to the cadence of the Latin language. Ovid too pointed out the ease of his own writing, indicating that whatever he tried to write, seemed to "came out in verse" (as he puts it in a masterly pentameter in Tristia 4.10.26: et quod temptabam scribere versus erat). Horace on the contrary underlines the effort required in producing lasting creative writing. ${ }^{21} \mathrm{He}$ refers to his poems as operosa carmina, (Odes 4.2.31-32). Just given the complexity of using Greek metre for Latin verse, the creative process must have been labourintensive or operosa indeed. ${ }^{22}$

Be that as it may, Horace stakes his claim as worthy successor especially to the great early Greek lyric poets by recalling their metrical ability and in turn, by proving his own mastery of metre. In doing so he also keeps reminding his audience of his Greek precursors in whose footsteps he follows so confidently.

That Horace uses metre as a mnemonic device is clear. How he exploits metre illustrates how successfully he employed this device. Horace opens his new lyric

17 Horace mentions Sappho by name in Odes 2.13.25.

18 spirat adhuc amor / vivuntque commissi calores / Aeoliae fidibus puellae, [her] love still breathes and the burning passions of the Aeolian girl committed to the lyre live on, Odes 4.9.10-12.

19 Explicit mention or listing of his contemporaries also serves as a simple mnemonic device to remember them, for instance mention of Maecenas, Augustus and other authors, like Agrippa, Odes 1.6 or Pollio, Roman consul, writing a history of the civil war and its causes, Odes 2.1. dicar ... princeps Aeolium carmen ad Italos / deduxise modos, I shall be spoken of ... as one who was the first to fit Aeolian song to Latin verse, Odes 3.30.10-14

21 Epistula 2.3, ad Pisos (de arte poetica) 291-294: vos, o / Pompilius sanguis, carmen reprehendite quod non / multa dies et multa litura coercuit atque / praesectum deciens non castigavit ad unguem, you o offspring of Numa Pompilius, must reject a poem that many days and much correction did not cut down to shape and improve ten times over to the point of a hair's breadth of difference (to the test of a close cut nail = metaphor from sculpture).

Ovid chose to refer to Horace as many-metred or numerosus (Tristia 4.10.41-42, et tenuit nostras numerosus Horatius aures / dum ferit Ausonia carmina culta lyra ) giving him his due in terms of Horace's own claim to fame. This seems to suggest that Horace's strict adherence to Greek metre in his carmina culta (belaboured songs) may have set an impossibly high (or should that be strained?) metrical standard for Latin lyric poetry, that subsequently left the field open for elegy and its more natural metrical fit to the Latin language. 
collection of odes with the so-called other Parade Odes (Odes 1.1-10) where he uses ten different Greek metres one after the after. Each metre is based on patterns created by or associated with Greek poets like Sappho, Alcaeus, Archilochus, Alcman, Asclepiades. The metres used by these and other Greek poets are distinct, memorable - and therefore easy to recognise throughout the whole collection of odes. Horace knows his educated audience was brought up on the Greek poets. ${ }^{23} \mathrm{He}$ can therefore safely assume that his audience will recognise the metrical patterns he has used to such remarkable effect in his own poetry. He can also assume that his audience will recognise his own exceptional abilities.

But Horace's audience does not only recognise patterns. They are also familiar with Greek and the Greek world reflected in the work of Horace's precursors. This means that echoes of the Greek language in Horace's poetry, such as the use of Greek constructions ${ }^{24}$ or a play on the original Greek meaning of words or names ${ }^{25}$ also function as a trigger to remind Horace's Roman audience of a Greek past that is now masterfully continued by a Roman artist. In addition contextual echoes, ${ }^{26}$ as well

23 A lyric poet like Horace had to take a learned predecessor like doctus Catullus into account. With Alexandrian and neoteric learning permeating the verses of his Latin predecessors, Horace could assume that his audience was at the least "well-read". Cf. Feldherr in Skinner 2007:98. One of the Greek poets that Horace mentions in Odes 4.9 (Simonides) is quoted by Cicero as an inventor of mnemonic systems (De Or. 2.352-253). Both Quintilian (Inst. 11.2; 11.3) and Tacitus (Ann. 11.14.2) stress the importance of memory and the need for systems to support memory. In Odes 3.30.12 (regnavit populorum) for instance, the unexpected genitive is emphasised by its reflecting "the imitation of a Greek construction" and is explained as a sign of "high stylistic level" (Williams 1969:151) which in turn implies that the audience would have registered it as such.

25 Word play where the Greek basis of the word has implications for the meaning of the Latin poem is common. For instance since Chloe's name is associated with "green vegetation" (Nisbet \& Rudd 2004:139), the implication is an emphasis on youth - either youthful inexperience that will be outgrown in the natural course of time as in Odes 1.23 or as an advantage over age as in Odes 3.9 where Chloe is described as Lydia's rival.

26 The following topics represent typical lyric preoccupations but can all be seen as reflecting Horace's Greek precursors as well: topics like avoiding to look into the future (permitte divis cetera, Odes 1.11); a lyric vs epic perspective on life (cano / canamus vs scribo; nos convivia, nos proelia virginum ... cantamus ... non praetor solitum leves, Odes 1.6. 17-20); being bound to a sportive lyre, pointing to the crux for whole collection at the end of the Parade Odes (te canam, magni Iovis et deorum / nuntium curvaeque lyrae parentem, / callidum quicquid placuit, iocoso / condere furto, Odes 1.10.5-8; Odes 3.3); seasons (passage of time) and the brevity of life (Odes 1.4.15: vita summa brevis spem nos vetat incohare longam:1.4.15, Odes 1.9 (Soracte); the voice of experience (Pyrrha in Odes 1.5); exploit the moment, make the most of today (carpe diem, Odes 1.11; dona preasentis cape laetus horae ac linque severa (gladly grasp the gifts of the present time and abandon serious concerns, Odes 3.8.27); enjoy life since an heir will take power over [your] riches (divitiis potietur heres, Odes 2.3; the heir may even be more worthy, absumet heres Caecuba dignior, 2.14.25); country [life is] hidden from harsh reality (in reducta valle, Odes 1.17); a Sabine valley unburdened by wealth (cur valle permute Sabina / divitias operosiores? Odes 3.1.47- 48); the burden of wealth (divitias operosiores, Odes 3.1.48); moderation: recognising human boundaries (Odes 1.3); sensibly avoid ostentation or a house that causes envy (rectius vives ... auream quisquis mediocritatem / diligit, .... caret invidenda / sobrius aula, Odes 2.10.1-8); be not anxious for the needs of life - life requires but little (nec trepides in usum poscentis aevi pauca Odes 2.11.4-5); death comes to all / position / wealth makes no difference (divesne, ... nil interest an pauper ... victima nil miserantis Orci, Odes 
as specific references to for instance, the Muses,${ }^{27}$ Greek gods, ${ }^{28}$ to Greek characters from Mythology, ${ }^{29}$ famous historical Greeks, ${ }^{30}$ to name but a few examples, repeatedly remind his audience of the great tradition that Horace continues.

But direct references are not the only type of reminder to keep the memory of Horace's precursors alive for his audience. Even association or intertextuality can serve this purpose. Here the reflection of a specific idea or incident associated with or recognised as one that occurred in a Greek precursor is the more interesting, since Horace's poetry, apart from standing on its own, in this case responds directly to what went before. Horace's cheerful admittance to having left his shield behind (Odes 2.7, relicta non bene parmula) is a direct reference to Archilochus fleeing from battle, leaving his shield behind, living to see another day - and of course, because of this, to being in a position to write the poem (fr. 5).

Not only ideas or expressions are taken over from Greek predecessors. More general examples of intertextuality occur where a poet like Horace reworks an original Greek or Alexandrian theme / topos. An example would be his use of the exclusus amator theme in for instance Odes 1.25, where Horace pushes the theme to its disconcerting and logical end. Lydia, initially in a position of power, is the traditional disdainful mistress scorning the excluded lover outside her closed door where he is pleading for admittance. At the end of the poem the positions have been drastically reversed. She has become the aged, spurned, exclusa amatrix, bewailing her former conquests and the irrevocable passage of time. Adding insult to injury is the disjunction or incongruity suggested by the Sapphic metre of the poem, commenting implicitly on flawed rather than satisfying human relationships. Here the

2.3.21-24); death is certain [no hall more certainly awaits the wealthy lord than the greedy underworld] (nulla certior tamen / rapacis Orci fine destinata / aula divitem manet / erum quid ultra tendis? Odes 2.18. 29-32) why strive for more than a sufficiency? (desiderantem quod satis est, Odes 3.1.25); what exile from his country ever escaped from himself as well? (patriae quis exsul / se quoque fugit? Odes 2.16 / 19-20); "ripeness" of time: Odes 1.23, 2.5; civic virtue (Odes 3.1-6).

27 References to the Muses include mention of the muses in general in Odes 1.6.10; Odes 1.17.14; Odes 26.1, 4, 9, 21; Odes 1.32.9; Odes 2.1.9, 37; Odes 2.10.9; Odes 2.12.13; Odes 3.1.3; Odes 3.3.70; Odes 3.19.13; Odes 4.8.28, 29 Pieris Pierides Odes 4.3.18; Odes 4.8.20; as well as specific muses such as Calliope (of epic poetry) Odes 3.4.2; Clio Odes 1.12.2; Euterpe (lyric song) Odes 1.1.33; Melpomene (tragedy) Odes 1.24.3; Odes 3. 30.16; Odes 4.3.1; Polyhymnia Odes 1.1.33; Thalia (comedy) Odes 4.6.25.

28 The Greek gods, whether they retain their Greek names or the Romanised version of those names, call up the Greek world, reminding the Roman audience of their Greek heritage. Examples are for instance Apollo in Odes 1.2.32; Odes 1.7.3, 28; Odes 1.10.12; Odes 1.21.10; Odes 1.31. 1; Odes 2.10. 20; Odes 3.4.64; Carmen Saeculare 34; Epod. 15.9; Bacchus in Odes 1.7.3; Odes 1.18.6; Odes 1.27.3; Odes 2.6.19; Odes 2.19. 6; Odes 3.3.13; Odes 3.16, 34; Odes 3.15.1; Diana (Cynthia) in Odes 3.28.12; Juppiter / Diespiter Odes 1.34.5; Odes 3.2.29.

29 References to Greek mythology include for instance Achilles Odes 1.15.34; Odes 2.4.4; Odes 2.16.29; Odes 4.6.4, Epod. 17. 14; Aeneas (as Trojan) Odes 4.6.23; Odes 4.7.15; Anchises, father of Aeneas Odes 4.15.11; Carmen Saeculare 50; Agamemnon Odes 4.9.25; Andromeda \& Perseus Odes 3.29.17; the Atrides (Agamemnon \& Menelaus) Odes 1.10.13; Odes 2.13.7; Ulixes, Ulysses Odes 1.6.7; Epod 16.60; 17.16; Bellerophon Odes 3.7.15; Odes 3.12.8; Odes 4.11.28.

$30 \quad$ Famous Greeks such as the philosophers Archytas Odes 1.28.2 and Pythagoras Odes 1.28.14; Epod. 15.21 as well as the sculptor Scopas Odes 4.8.6. 
metre is used to enhance what in essence is a harsh threat, even if the reworking of the stock paraclausithyron ${ }^{31}$ theme in such realistic detail, is surprisingly successful.

However, by using recognisable Greek examples so profusely, Horace not only supplies his audience with a handy aide-mémoire to his predecessors, he also takes up the burden to continue the Greek lyric tradition. By bringing into play the original Greek poetry associated with a specific poet or metre, Horace's own poetry comments on or engages with the work of his precursors. The reference to his (and Archilochus') abandoned shield thus also contains a reference to the natural instinct for self-preservation expressed by two lyric poets that in turn represents a dig at epic where heroes seem prepared to throw away their lives without further ado. This is a perspective associated primarily with lyric's focus on the individual. The idea of lyric is thus continued in Horace's take on the incident.

Horace's work as aide-mémoire does not only embody fleeting reminders of the Greek world of lyric that preceded his word, he also reminds his audience of his precursors in a more sustained fashion. I will look more closely at only two of the Greek poets with whom Horace engages in this way. ${ }^{32}$

The Alcaic metre used so strikingly in all six of the Roman Odes (Odes $3.1-$ 6) not only gives a distinct sound to each of the poems. The Alcaic association imbedded in the metre also holds up as foil - against which the Roman poet should be read - the original work of the Greek poet Alcaeus who focused on life's vicissitudes and the grim consequences of war. ${ }^{33}$ Like a basso continuo, the metre and the example contained in Alcaeus' oeuvre, keep the grim reminder of Greek decline before the Roman audience in each of the Roman odes. ${ }^{34}$ The Roman people's ongoing moral and physical decline continues this trend as it were sub specie aeternitatis. The fact that this is a social pattern that keeps repeating itself, adds to the gravitas of the Roman odes - an important perspective for a lyric poet who usually concerns himself with individual issues rather than public or collective experience.

Horace also engages directly with the poetry of the Greek lyric poetess, Sappho, who was especially concerned with individual experience and understanding of life. Even for Horace, the classic example of using the content of a Greek precursor

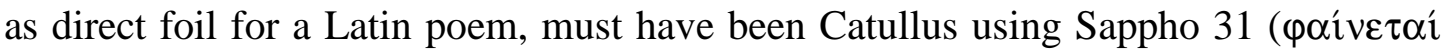

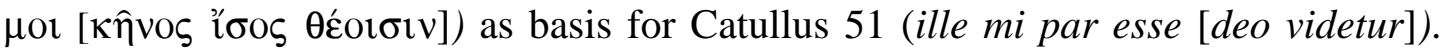
The experience described in the Catullan poem assumes detailed memory of its

$31 \quad$ Nisbet \& Rudd 2004:141 defines a paraclausithyron as "the lament sung by an excluded lover in front of the woman's closed door" further indicating that this type of lament is "attested as early as Alcaeus 374 L-P"; also that "Hellenistic epigrammatists provide variations on the theme".

32 Horace's use of his Greek precursors individually and collectively has been the topic of academic research for many years. Cf. Oates' The influence of Simonides of Ceos on Horace, a dissertation dated from 1932 referred to in the more recent survey by Feeney of Horace's debt to Greek lyric in general (1993:41-63).

33 For Horace the poetry of Alcaeus focused on life's harshness (dura): et te sonantem plenius aureo /Alcaee, plectro dura navis, / dura fugae mala, dura belli, and you, Alcaeus, resounding more fully with a golden plectrum, the harsh circumstances of the seafarer, the harsh evils of the refugee, the harsh travails of war, Odes 2.13.26-28.

34 aetas parentum, peior avis, tulit / nos nequiores, mox daturos / progeniem vitiosiorem, the age of our parents, worse than our grandparents', has produced us - worse (yet again) - the ones soon about to produce an even more evil generation, Odes 3.6.46-48. 
forerunner. Catullus 51 cannot be read without Sappho 31 sounding clearly in the background and commenting implicitly on the Latin poem.

In the same way, the sly wit of Odes 3.8, where Horace as a bachelor celebrates the Matronalia - a feast held exclusively for married women - is underlined by the Sapphic metre of the poem. Because of this supposed holiday, Horace is free and wants his friend Maecenas to celebrate the day with him. In the poem expressing this wish, a metre, normally associated with the great love poetry of Sappho with its focus on relationships, is used to celebrate a bachelor's freedom from entanglements and his focus on carpe diem. ${ }^{35}$ However, there $i$ s a relationship at stake in this poem - that of friendship between Horace and Maecenas. And Horace wants what any lover would want - some unencumbered time with his friend. In this way the Sapphic metre at first apparently suggests a witty incongruity between the original and its application in Odes 3.8. In the end though, the Sapphic metre reinforces the poem's complexities by reminding the reader (and especially the addressee, Maecenas) of the importance of human relationships. The metre, furthermore, reminds the audience of the mastery of both the original and the present poet. Horace has written a new Latin lyric poem - but the audience has heard the Sapphic echo and is directly reminded of one of the great masters of the past.

Horace's work does not only function as an aide-mémoire for the work of his precursors. His work also becomes the repository for memory of real events that form part of Horace's individual experience and of the communal experience of Horace's contemporary audience. These real events underpin the author's aim in reworking living reality into a literary achievement that becomes accessible to generations of readers not only by means of individual memory but also via a collective memory of common human experience. ${ }^{36}$ This memory, individual or collective, becomes the springboard from which the future can be approached.

It is because as a lover Horace is reminded of his own past lapses that he can turn around (poetically at least) a situation of individual emotional loss and open up a new future. The temple wall (the paries sacer of Odes 1.5) exhibits the evidence of a young man's near fatal brush with experience. The votive tablet serves as a permanent reminder of his being subjected to the danger of Pyrrha's changeable sea. ${ }^{37}$ However, Horace survived to tell the tale, offering his audience his own individual version of a Song of Innocence and Experience.

Neobule (Odes 3.12) has learned through personal experience that the remedies open to an exclusus amator, do not work for a female in the same position. If, however, in memory of others who preceded her, who shared her experience, she puts her position into words, the situation becomes memorable and with

35 As Horace indicates at the end of the poem in dona praesentis cape, take the gifts of the present, Odes 3.8.27.

36 Leach 1998:46 refers to Verrall 1884:90-120, indicating that a "sequence of 'historically based' poems established a frame for the reader's experience of the book." She goes on to point out that "visible events, available to the contemporary reader through memory stand out as temporal markers to be grasped in their relationship to the moment of reading" (1998:46).

37 me tabula sacer / votiva paries indicat uvida / suspendisse potenti / vestimenta maris deo, the temple wall with votive tablet indicates that I have hung up my wet clothes to (in acknowledgment of) the powerful god of the sea, Odes 1.5.13-16. 
remembrance, some order is imposed on or sense is made of experience. Whether this personal memory will serve to avoid a similar situation in future, is not at issue here. What is at issue is that a situation of loss has been transformed into a poem. Memory will take the poem with it and not the original experience of loss.

It is because Horace can rely on the collective memory of a time when citizens readied the sword against each other (civis acuisse ferrum, 1.2.21) that he can call upon the Roman people to work together towards a better future without war (Odes 1.2) ${ }^{38}$ This is a remarkable leitmotif for Horace - given that he is a lyric poet more interested in convivial themes, such as the battles between the sexes rather than the epic battles of war (Odes 1.6). ${ }^{39}$ This reminder of past battles and the call to unite for a better future happens to be a motif to which Horace returns in each of his Books of odes. Immediately after his dedicatory ode to Maecenas (Odes 1.1), Horace chooses as the second poem of his first Book of Odes, a poem that points out that a continuation of the civil war must be avoided. ${ }^{40}$ In the opening poem of his second Book of odes, the lyric poet Horace finds it necessary once again to remind his audience of the horrors of civil war. He opens Book Two with an address to Pollio, who is writing a history of the civil strife (metum ... civicum, 2.1.1) and its causes (bellique causas, 2.1.2). ${ }^{41}$ It is as if Horace has to make sure that memory of the civil war can never be eradicated in his audience before he turns to the themes more suited to his lyric muse in the rest of Book Two. ${ }^{42}$ However, in his Roman odes, the first six poems of Book Three, Horace, once again, returns to war and the memory of war. ${ }^{43}$ Horace ends his Roman odes in despair since collective memory did nothing to avoid an even more damning future. ${ }^{44}$ Significantly Horace's fourth and final Book of Odes, that saw the light some time after the first three Books were published, ${ }^{45}$ again takes up the theme of civil war. It is much less pronounced than in the previous three Books, since time has lessened the immediate threat of war. However, it remains necessary for Horace to point out that curae sagaces (wise forethought) will continue

38 grave ne redirect / saeculum Pyrrhae, lest the burdensome age of Pyrrha return, Odes 1.2.5-6.

39 nos convivia, nos proelia virginum sectis in iuvenes unguibus acrium cantamus, I, I sing of feasts, of the battles of girls with trimmed finger nails [fighting] young men, Odes 1.6.17-19.

40 The error of the previous generations where youth paid the price for their elders' offence (vitio parentum / rara iuventus, Odes 1.2. 23-24) must not be perpetuated by a similar transgression of the present generation vitio parentum (1.2.23) vs nostris vitiis (1.2.47).

41 Since the memory of civil war is still so fresh, this reminder is not for the present but for future generations who may forget that once no blood-drenched river failed to bear witness to war and that no coast was ignorant of Roman blood (quae flumina lugubris ignara belli?, which rivers [are] ignorant of grim war, Odes 2.1.33-34), quae caret ora cruore nostro? which coast lacks our [Roman] blood? Odes 2.1.36).

42 As Horace puts it at the end of this introductory poem: mecum ... quaere modos leviore plectro, seek with me for metres (themes) with a lighter touch, Odes 2.1.40.

43 Because collective memory has not served its purpose a generation wallowing in sin (fecunda culpae saecula, 3.6.13) has come forth, instead of a generation who managed to act on the lessons that memory provided, who managed to redeem the mistakes of the past.

44 aetas parentum, peior avis, tulit / nos nequiores, mox daturos / progeniem vitiosiorem, the age of our parents, worse than our grandparents' time, has produced us - worse (yet again) - (and we are the ones) soon to produce an even more evil generation, Odes 3.6.46-48.

45 Odes Books 1-3 were published in 23 BC. The publication date of Odes Book 4 is generally taken as $13 \mathrm{BC}$. 
to be needed to avoid even the threat of war (curae sagaces / expedient per acuta belli, Odes 4.4.75-76).

Specific indications of a period, such as references to civil war for instance, can speak to subsequent readers but never as part of the individual memory underpinning the original experience of the poems. However, whatever these indicators may be for the original audience, the subsequent reader can share in this communal memory of events. In this case the reader shares the general cultural memory of similar events. The reader does not share the individual memory of the particulars. Finally poetic representation appeals to common experience (a common shared memory) for its effectiveness. And in the end not only the events are remembered in poetry, but also the poet.

Given the quality of Horace's work and the fact that he consistently and in different ways reminds his audience of his Greek predecessors (and of his own time) it is clear that Horace's work has become a repository for lyric memory. However, in order for his work not only to be but also to continue operating as an aide-mémoire, someone has to remember Horace.

Today when we read Horace, not only the ancient Greeks, the Alexandrians and the ancient Romans resound in his poetry. If we look at the reception of Horace since the Renaissance, much of a specific age is reflected in their approach to and interaction with this Roman poet. The reception of Horace, that is, responses to Horace in new literature or in books or articles about Horace, invariably reflect the concerns, "the conscious or unconscious thoughts and social institutions" 46 of the age responding to Horace's oeuvre. At the same time this response reinvents but also continues the original tradition founded by the early Greek lyric poets.

This is not the place for a thorough engagement with the reception of Horace through the ages. A single example will have to suffice. A poet such as Wilfred Owen writes a poem titled Dulce et decorum est pro patria mori. This title refers us directly to Odes 3.2.13 even though the line originally occurs in Tyrtaeus fr. 10.1-2 (also in Simonides, Harrison 2001:260-271). However the Horatian context of this line has fundamental implications for its meaning in the Owen poem. In the Horace poem the line is preceded by a call not to rush to arms like a savage beast whose bloody rage (ira cruenta, Odes 3.2.11-12) thrusts him towards mindless bloodshed (per medias ... caedes, Odes 3.2.12). In the following line Horace furthermore questions the value of dying for the fatherland in the first place. The rest of the poem is at great pains to argue that civic virtue and a life of quiet contemplation is as valuable to the fatherland, since something as passive as silence too can claim not only a reward, but

46 In a recent Bryn Mawr review Lee Pearcy points out that "books can themselves become objects of study revealing the conscious or unconscious thoughts and social institutions of the people who use them." From: bmcr-1-bounces@brynmawr.edu [mailto:bmcr-l-bounces@brynmawr.edu] On Behalf Of Bryn Mawr Reviews Sent: 16 July 2008 22:35 To: Bryn Mawr Classical Review Subject: BMCR 2008.07.38, Christopher Stray (ed.), Classical Books: Scholarship and Publishing in Britain Since 1800. Bulletin of the Institute of Classical Studies, Supplement 101. London: Institute of Classical Studies, School of Advanced Study, University of London, 2007. Pp. vi, 188. ISBN 978-1-905670-15-4. Reviewed by Lee T. Pearcy, The Episcopal Academy and Bryn Mawr College (lpearcy@brynmawr.edu). 
a sure one (tuta...merces, Odes 3.2.25-26). ${ }^{47}$ In the end death, the great equalizer, overtakes soldier and civilian alike (mors et fugacem persequitur virum, 3.2.14) supporting a pronounced ironic take on the allegedly positive idea that death benefits the fatherland (dulce et decorum est pro patria mori, Odes 3.2.13). The perspective supplied by the Horatian aide-mémoire therefore reinforces the basic thrust of the subsequent Owen poem. Memory of what Horace wrote, would colour any reader's expectation of the Owen poem and even a supposedly positive statement may have many different ramifications.

In conclusion something more general: many of our school and university mottoes still rely on Horace and others to provide a suitable Latin phrase to indicate something of the ambiance and aim of a specific institution. The University of Melbourne shares Horace's own vision for continuing recognition in future in crescam laude recens, I shall grow, always renewed in [future] glory, (Odes 3.30.8). The University of Stellenbosch proudly proclaims pectora roborant cultus recti (a sound education strengthens character, Odes, 4.4.34). My personal favourite is the Horace instruction sapere aude (dare to taste / browse Epistles 1.2.40) used at the entrance to the Classics Library at the University of Tübingen - probably the most immediately "unproductive" but at the same time best possible advice for those who enter. Such mottoes may not elicit immediate recognition of the source in a contemporary audience, but they do represent an ongoing reminder of that original thought. In this manner they, just like Horace's odes, reinforce the collective memory of the original. Both serve as solid preservation of the past, an ongoing cultural aidemémoire to a new generation.

\section{BIBLIOGRAPHY}

Feeney, D C 1993. Horace and the Greek Lyric Poets. In Rudd, N (ed.) Horace 2000: Essays for the Bimillennium, 41-63. London: Duckworth.

Gowing, A M 2005. Empire and memory: the representation of the Roman Republic in imperial culture. Series: Roman Literature and its Contexts. Cambridge: Cambridge University Press.

Feldherr, A 2007. The intellectual climate. In Skinner, M B (ed.) A companion to Catullus, 92-110. Oxford: Blackwell.

Harrison, S J 2001. Simonides and Horace. In Boedeker, D \& Sider, D (eds.) The new Simonides: Contexts of Praise and Desire, 260-271. Oxford: Oxford University Press.

Kapuscinski, R 2008. Travels with Herodotus. London: Penguin (originally published in Krakow in 2004).

Leach, E W 1998. Personal and communal memory in Horace's Odes. Arethusa 31: 43-74.

McNeill, R L B 2007. Catullus and Horace. In Skinner, M B (ed.) A companion to Catullus, 357-376. Oxford: Blackwell.

47 This perspective is worked out in more detail in Thom 1998:57-59. 
Nisbet, R G M and Rudd, N 2004. A commentary on Horace, Odes, Book III. Oxford: Oxford University Press.

Race, W H (ed. \& trans.) 1997. Pindar I: Olympian Odes, Pythian Odes. LCL 56; Pindar II: Nemean Odes, Isthmian Odes, Fragments LCL 485. Harvard University Press: Cambridge, Mass.

Skinner, M B (ed.) 2007. A companion to Catullus. Oxford: Blackwell.

Thom, S 1998. Lyric double talk in Horace's Odes 3.1-6. Akroterion 43:52-65.

Williams, G 1969. The third book of Horace's Odes. Oxford: The Clarendon Press. 